\title{
Demanda e oferta energética: uma perspectiva mundial e nacional para o etanol'
}

\author{
Fernanda Schutz ${ }^{2}$, Angélica Massuquetti ${ }^{3}$, Tiago Wickstrom Alves ${ }^{4}$ \\ 'Programa de Pós-Graduação em Economia (PPGE) - Universidade do Vale do Rio dos Sinos (UNISINOS) \\ ${ }^{2}$ Mestre em Economia pelo Programa de Pós-Graduação em Economia (PPGE) - Universidade do Vale do Rio dos Sinos (UNISINOS) \\ ${ }^{3}$ Professora do Programa de Pós-Graduação em Economia (PPGE) da Universidade do Vale do Rio dos Sinos (UNISINOS). \\ ${ }^{4}$ Porfessor do Programa de Pós-Graduação em Economia (PPGE) - Universidade do Vale do Rio dos Sinos (UNISINOS)
}

\begin{abstract}
Resumo
O objetivo do artigo é avaliar a oferta e a demanda de energia no mundo e no Brasil, para os próximos 15-20 anos, e especialmente as perspectivas para o etanol. A metodologia empregada foi a revisão bibliográfica e a análise de cenários futuros a partir de dois estudos, International Energy Outlook 2011 e Plano Nacional Energético 2030. Os resultados demonstram que as perspectivas para o consumo, tanto de combustíveis líquidos quanto de etanol, são otimistas, gerando a expansão da produção. No período analisado não está prevista uma ruptura da atual matriz energética, mesmo com um pequeno aumento da participação das fontes renováveis no total de energia demandada.
\end{abstract}

Palavras Chave: Demanda energética; Oferta energética; Etanol.

\begin{abstract}
This paper estimates the bilateral trade flows between the BRICs - Brazil, Russia, India and China - in the next decades. This study employs a gravity model based on a sample of 57 countries. Trade flows and a variety of other data were collected from 2000 to 2007 to enable the estimation of gravity equations that explain the international trade in this period. By using two different estimation methods - OLS and Tobit - a wide set of parameters was generated, with the aim to choose the most adequate equations for the estimations wanted. Finally, these two best parameter sets were arranged and applied on gravity equations, combined with the Goldman Sachs predictions, in order to obtain future estimations of bilateral trade flows between them in three time-scenarios: short term (2010), midterm (2020) and long term (2030). The results show that the 'intra-BRICs' trade flows will grow even more than the GDP of these countries, meaning an increase in the interdependence among these economies, contributing to maintain their economic growth.
\end{abstract}

Keywords: Energy demand; offer energy; Ethanol. 


\section{INTRODUÇÃO}

Ao longo da história, diversas foram as fontes e as formas de energia utilizadas: força humana, tração animal, vapor, carvão, petróleo e derivados, biomassa, água, vento, eletricidade, dentre outras. Elas foram empregadas como meio para a produção de bens e de serviços. Se, por um lado, o uso da energia contribui para a sociedade como um todo, por outro, apresenta limites, questionamentos e desafios na medida em que gera impactos sobre o meio ambiente e os indivíduos. Neste sentido, destaca-se a energia gerada a partir de combustíveis fósseis, como o petróleo em função dos limites de suas reservas mundiais; as emissões de $\mathrm{CO}_{2}$, como uma das causas apontadas para o aquecimento global; e os desastres ecológicos a partir da perfuração de poços de petróleo.

Com isso, diversos tópicos estão no centro das discussões e das preocupações mundiais: as mudanças climáticas e o aquecimento global, o meio ambiente, a questão energética, dentre outros correlacionados. A economia apresenta estrita relação com todos, dada a dependência notória da sustentação das atividades econômicas. Dentre os quais, avulta-se a questão energética: uma das bases fundamentais para a produção de bens e de serviços, destacando-se a produção de etanol, a qual faz parte de uma ampla discussão de possibilidades e de oportunidades econômicas e ambientais de energias renováveis, juntamente com a energia solar e eólica.

Neste sentido, as fontes energéticas apontam o caminho escolhido pelas nações em termos econômicos, pois as escolhas são pautadas pelos padrões mundiais de produção e consumo de toda sociedade. A matriz energética sofreu modificações ao longo do tempo, contudo, hoje é possível afirmar que estamos em uma era das fontes energéticas de origem fósseis. Mesmo com processos de busca e introdução de energias limpas e renováveis, o mundo continua investindo na procura de novas reservas de petróleo e de outros materiais. Haja vista o Brasil com uma contradição nacional, com o investimento no Programa Pré Sal e o etanol como combustível limpo e alternativo.

Neste sentido, o presente artigo apresenta um panorama atual da matriz energética mundial e nacional, bem como resultados de estudos realizados que apontam, num horizonte de 15 a 20 anos, o comportamento dos energéticos utilizados para atender as necessidades e demandas da sociedade. $\mathrm{O}$ artigo está divido em quatro seções. Além desta parte introdutória, a segunda seção aborda brevemente a conceituação de energia e de biomassa e como se classificam e o panorama mundial e nacional da matriz energética. Após, apresentam-se cenários futuros para oferta e consumo energético. $O$ etanol é o centro da quarta seção, com a discussão sobre sua produção e consumo e perspectivas. Por fim, são apresentadas as principais conclusões do estudo.

\section{ENERGIA, BIOMASSA E MATRIZ ENER- GÉTICA}

\section{I CONCEITO E CLASSIFICAÇÃO}

Para Goldemberg e Lucon (2008), a energia está relacionada com a capacidade de se realizar e produzir trabalho, sendo a manifestação resultante da utilização de uma força externa capaz de deslocar algo. Hinrichs e Kleinback (2003, p. 2) esclarecem que a "[...] energia não é criada ou destruída, mas apenas convertida ou redistribuída de forma para outra, como, por exemplo, a energia eólica é transformada em energia elétrica ou a energia química em calor". Além disso, para os mesmos autores, há várias formas de energia: mecânica elétrica, química, térmica, radiante e nuclear. O U. S. Energy Information Administration (EIA) classifica a energia, considerando as suas diferentes formas (elétrica, calor, química e de movimento) e dividindo-as em duas grandes categorias (energia potencial e energia cinética). A energia potencial é a armazenada, podendo se apresentar como química, mecânica, nuclear, gravitacional. Já a energia cinética está relacionada com o movimento, tais como: motora, elétrica, termoelétrica, radiação, dentre outras (EIA, 2012a).

Para a elaboração do Balanço Energético Nacional (BEN), a Empresa de Pesquisa Energética (EPE) utiliza as seguintes fontes primárias de energia: petróleo, gás natural, carvão vapor, carvão metalúrgico, urânio $\mathrm{U}_{3} \mathrm{O}_{8}$, energia hidráulica, lenha, produtos da cana, outras fontes primárias. Já as secundárias são: óleo diesel, óleo combustível, gasolina, gás liquefeito de petróleo (GLP), nafta, querosene, gás cidade e coqueira (derivados do petróleo), álcool etílico, anidro e hidratado (produtos da cana), coque de carvão mineral, urânio contido no $\mathrm{UO}_{2}$, eletricidade, carvão vegetal, produtos não energéticos do petróleo e alcatrão (EPE, 2011).

No Quadro 1, é possível visualizar a classificação de fontes energéticas ao considerar sua relação temporal de reposição. As fontes energéticas não renováveis estão relacionadas com uma origem fóssil. Já as renováveis apresentam como característica principal a sua composição em bio- 
Quadro 1 - Classificação de fontes energéticas

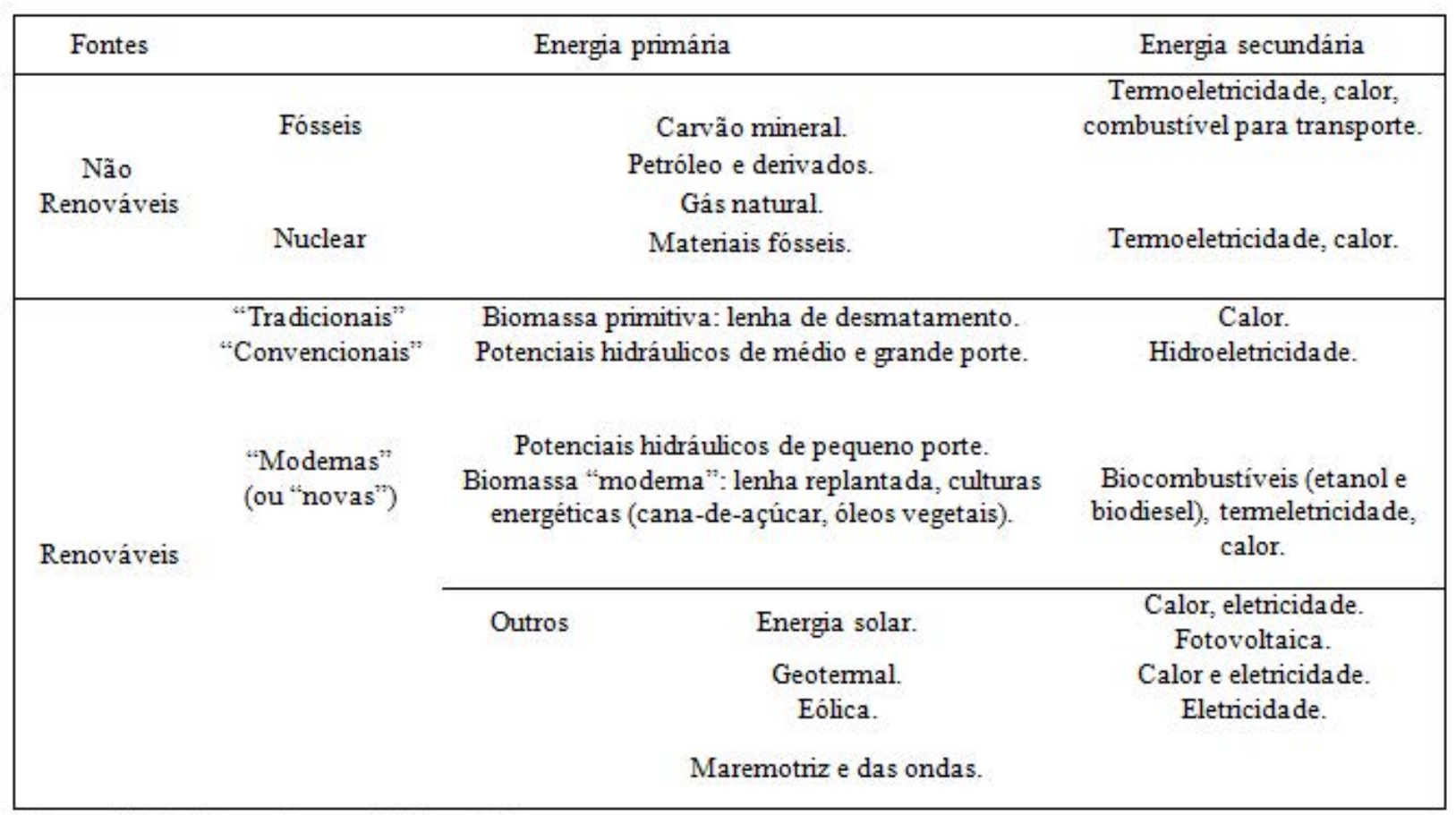

Fonte: Goldemberg e Lucon(2008, p. 69).

massa, ou seja, matéria viva ou recentemente viva.

As fontes renováveis são subdivididas em três categorias: 1) tradicionais; 2) convencionais; e 3) modernas. As tradicionais estão ligadas à produção de calor, a partir da queima direta de material orgânico, como a madeira, o carvão vegetal e os resíduos orgânicos em geral. E, assim, é tida como a forma mais primitiva da utilização da biomassa. As formas convencionais estão relacionadas às hidrelétricas, produtoras de energia elétrica. No que tange à biomassa moderna, esta inclui processos de conversão avançados da mesma, como os biocombustíveis. É nesta categoria que se encontra o etanol, um biocombustível derivado das mais diversas biomassas e o qual é utilizado, principalmente, no setor de transportes.

Não distante da importância da clareza do termo energia, conforme já destacado, a mensuração e a apresentação dos dados dos mais variados recursos energéticos também são postas como fator relevante. Assim, cada recurso energético pode ser medido com uma unidade específica. Para os combustíveis líquidos, utilizam-se, em geral, metros cúbicos $\left(\mathrm{m}^{3}\right)$, barril (bbl) e litros (l). Os gasosos também podem ser medidos $\mathrm{em}^{3}$ ou pés cúbicos (pé3). Os sólidos, em geral, são mensurados em toneladas $(\mathrm{t})$ e para a energia elétrica: watt-hora (Wh) e potência watt (W). A fim de poder comparar de forma homogênea os recursos energéticos, utiliza-se uma unidade comum, na qual os mesmos são convertidos. Dessa forma, podem ser convertidas em toneladas equivalente de petróleo (tep), toneladas equivalente de carvão (tec), British Thermal Unit (BTU), joule, calorias, entre outros (REIS et al., 2012).

Os organismos responsáveis em sistematizar, analisar e disponibilizar dados e informações referentes às questões energéticas convertem os recursos em unidades comuns 1 já citadas. Pode-se mencionar como exemplo o BEN, o qual utiliza como unidade comum o tep. Os dados de consumo mundial de energia primária, extraídos do EIA, estão convertidos em BTUs. Para finalizar o exposto, destacam-se as duas razões pelas quais o tep é a medida básica adotada no BEN: 1) "está relacionada diretamente com um energético importante" e; 2) "expressa um valor físico" (EPE, 2011, p.193). Os recursos e as reservas brasileiras apresentadas na Tabela 1 referem-se às fontes primárias de energia de origem fóssil com dados comparativos dos anos de 1988 e 2010.

Os dados revelam, por exemplo, que o

1 A fim de uniformizar os dados agregados, adotou-se o tep e suas derivações (Mtep: Milhões de tep ou $10^{6}$ tep; $10^{3}$ tep: Mil tep) como medida padrão. Quando não for possível a sua utilização, a medida adequada será relacionada e explicada conforme necessidade. 
Tabela 1 - Recursos e reservas energéticas brasileiras dos anos 1988 e 2010Fonte: Brasil (2013); Acioli (1994).

\begin{tabular}{crrrrrrr}
\hline Fontes & Unidade de medida & Medidas/indicadas (inventariadas) & Inferidas (estimadas) & \multicolumn{2}{c}{ Total } \\
& & 1988 & 2010 & 1988 & 2010 & 1988 & 2010 \\
\hline Petróleo & $10^{3} \mathrm{~m}^{3}$ & 447.730 & 2.264 .981 & - & 2.260 .970 & 447.730 & 4.525 .951 \\
Gás Natural & $10^{6} \mathrm{~m}^{3}$ & 108.900 & 423.003 & - & 401.720 & 108.900 & 824.723 \\
Carvão Mineral & $10^{6} \mathrm{t}$ & 10.215 & 25.771 & 22.206 & 6.535 & 32.421 & 32.306 \\
\hline
\end{tabular}

Fonte: Brasil (2013); Acioli (1994).

Notas: As reservas de petróleo estão expressas em milhares de $\mathrm{m}^{3}$, de gás natural em milhões de $\mathrm{m}^{3}$ e as de carvão mineral em milhões de t. As unidades de medidas utilizadas nesta Tabela refletem as usualmente empregadas para medir cada um dos recursos energéticos listados. Como o objetivo é informar e comparar as reservas indicadas e inferidas dos mesmos, em períodos distintos, manteve-se as unidades padrão de cada recurso.

desenvolvimento tecnológico, de alguma forma, contribuiu para o aumento das reservas de petróleo significativamente. Ao comparar os anos de referência, observa-se um aumento de $506 \%$ das reservas provadas de petróleo no Brasil. As reservas de gás natural e de carvão mineral aumentaram, respectivamente, $388 \%$ e $252 \%$. A extração de petróleo na chamada "camada pré-sal", desde 2008 , tem colaborado para este aumento e segundo a Petrobrás (2013), estima-se que o Brasil chegará a 1 milhão de barris/dia, em 2017.

Outra importante fonte energética é a biomassa $^{2}$, umas das principais produzidas e consumidas no mundo. A biomassa deriva de material que tenha origem viva, orgânica, podendo ser animal, vegetal e micro-organismos, e que pode ser empregado para a produção de energia (CENBIO, 2012). Mais especificamente, está relacionada com uma variedade de materiais orgânicos, os quais podem tomar diversas formas, tais como: cultivares, madeira, serragem, palha, estrume, lixo de papel, refugo doméstico, esgotos, entre outros. Além disso, os resíduos oriundos após a sua utilização também se configuram como fontes energéticas. São exemplos de resíduos: os florestais e agrícolas e a matéria-orgânica, tanto de processos industriais quanto domésticos, comerciais e rurais (REIS et al., 2012).

A biomassa pode ser utilizada como fonte de energia, direta ou indireta. Diretamente, se produz calor como produto energético imediato, através da sua combustão. A forma indireta é

2 O termo biomassa está relacionado com uma série de vegetais presentes na natureza, os quais têm origem a partir do processo de fotossíntese. Ao absorverem energia solar, água e dióxido de carbono, transformam esses elementos em energia potencial química (REIS et al., 2012). a combustão após passagem por um processo, podendo este ser: físico, termodinâmico (pirálise, gaseificação e liquefação) ou biológico (digestão anaeróbica e fermentação), originando uma segunda fonte energética, podendo ser sólido, líquido ou gasoso. Exemplos de fontes energéticas secundárias de biomassa são: biocombustíveis, lenha, carvão vegetal e gás. Neste sentido, a energia química potencial armazenada nas plantas pode ser utilizada na forma de combustíveis.

A biomassa apresenta-se como fonte predominante na matriz energética de "[...] alguns países como o Quênia, Índia, Brasil e outros da América do Sul, Ásia e África [...]" (REIS et al., 2012, p. 281). Assim, a Tabela 2 mostra a produção de energia a partir da biomassa, no mundo, considerando os dados disponíveis para o período de 1999 a 2003.

Ao comparar ano a ano, o incremento de 1999 para 2000 decresceu em 0,34\%. Nos anos seguintes, os incrementos foram positivos: 2000/2001: 0,64\%; 2001/2002: 0,55\%; e 2002/2003, o incremento foi de $1,42 \%$, tendo uma média anual de $0,57 \%$ de aumento de energia de biomassa. A Ásia e a Austrália são os maiores produtores de energia de biomassa, respondendo, em 2003, por $36,88 \%$. O segundo lugar é ocupado ora pela África, ora pela América Latina. A América Latina foi a região do mundo em que a produção de energia de biomassa mais aumentou, em média, 2,28\% ao ano. O incremento médio anual da África, da Ásia e Austrália, Europa Ocidental e da Rússia-Europa Oriental ficou em $0,20 \%$, enquanto que o Oriente Médio se manteve constante (CORTEZ et al., 2008).

A partir do exposto, as subseções que seguem são dedicadas a explorar e analisar a 
Tabela 2 - Produção de energia a partir da biomassa nas principais regiões mundiais no período de 1999 a 2003 (106 tep)

\begin{tabular}{cccccc}
\hline Região Mundial & 1999 & 2000 & 2001 & 2002 & 2003 \\
\hline África & 721,2 & 722,64 & 724,08 & 725,53 & 726,98 \\
América do Norte & 591,71 & 593,55 & 595,4 & 597,26 & 599,12 \\
Ásia e Austrália & $1.545,39$ & $1.548,49$ & $1.551,58$ & $1.554,68$ & $1.557,79$ \\
Europa Ocidental & 253,42 & 253,93 & 254,44 & 254,95 & 255,46 \\
América Latina & 700,25 & 678,54 & 697,41 & 712,78 & 764,33 \\
Oriente Médio & 7,93 & 7,93 & 7,93 & 7,93 & 7,93 \\
Rússia - Europa Oriental & 310,36 & 310,98 & 311,6 & 312,23 & 312,85 \\
Total & $4.130,26$ & $4.116,06$ & $4.142,44$ & $4.165,36$ & $4.224,46$ \\
\hline
\end{tabular}

Fonte: Olade (2004 apud CORTEZ et al., 2008, p.16).

atual matriz energética no mundo e no Brasil, apresentando a demanda e a oferta de energia.

\subsection{OFERTA E DEMANDA ENERGÉTICA MUNDIAL}

Os padrões de oferta e demanda de energia sofreram modificações ao longo da história. Podem-se destacar alguns momentos importantes na transformação da matriz energética, como: o uso da madeira como um dos primeiros energéticos utilizados pelo homem; a sua substituição pelo carvão mineral em escala e a introdução do petróleo como principal energético atualmente. A substituição ou menor uso em escala da madeira pelo carvão dá-se, primeiramente, na Europa. Devido à intensificação de sua utilização, por volta do século XVI, e sua consequente escassez, o carvão passa a ser o principal energético a ser utilizado, a partir da segunda metade do século XVIII. Contudo, na América do Norte, o uso intenso da madeira, como fonte principal, ainda estava posto, dada a sua abundância. O carvão mineral passa a ser empregado em escala no continente americano, no século XIX, e responde por $53 \%$ do consumo mundial de energia. Desta forma, esta pode ser a primeira grande mudança da matriz energética: a substituição da madeira em larga escala pelo carvão mineral (REIS et al., 2012).

O outro destaque é a introdução do petróleo na matriz energética com exploração a partir de 1853, nos Estados Unidos da América (EUA). A sua introdução em escala não está relacionada com uma possível escassez do carvão mineral, o qual ainda é bastante empregado em alguns setores da economia. Porém, começava a emergir a necessidade de um energético que atendesse às demandas de uso final, transporte e armazenamento, e aos avanços tecnológicos que estavam ocorrendo naquele período (REIS et al., 2012).
Fatores como o desenvolvimento tecnológico voltado para a extração e a produção; a transmissão e a distribuição de energia; a descoberta de novas fontes de energia; a evolução da produção e do consumo de bens e serviços; o crescimento econômico e populacional; entre outros, justificam as transformações e as substituições de fontes energéticas. Seja para manter os padrões de crescimento, seja para garantir o desenvolvimento e atender as mais diversas necessidades e desejos da sociedade.

Segundo Goldemberg e Lucon (2008, p.61), "o desenvolvimento significa satisfazer as necessidades humanas básicas, incluindo acesso a emprego, alimentação, serviço de saúde, educação, moradia, água corrente, tratamento de esgoto, etc.". Os mesmos destacam que o padrão de consumo energético está diretamente relacionado com o nível de renda e que o perfil do uso energético é fundamentalmente diferente entre ricos e pobres. Enquanto aqueles procuram imitar um estilo de vida prevalecente em países industrializados, apresentando padrões voltados para um consumo de luxo, estes últimos têm sua preocupação centrada em energia suficiente para prover as necessidades mais básicas e essenciais.

Ainda, segundo os mesmos autores, em 2004, o consumo per capita de energia dos 6,35 bilhões de habitantes no mundo foi, em média, de 1,77 tep, aproximadamente, um milhão de vezes maior que o consumido pelo homem primitivo. No mesmo ano,

[...] cada africano consumiu em média 0,67 toneladas equivalentes de petróleo (tep); cada brasileiro 1,11 tep; cada chinês 1,25 tep. Em compensação cada habitante dos países desenvolvidos da OCDE consumiu 4,73 tep de energia nesse ano; cada cida- 
dão dos EUA 7,91 tep (GOLDEMBERG; LUCON, 2008, p. 58-59).

Percebe-se que há uma diferença no consumo médio de energia, por habitante, quando comparado à média mundial. Esses dados reforçam a relação dos padrões de consumo com as necessidades energéticas nos mais diversos locais. O cidadão estadunidense consumiu, em 2004, aproximadamente 4,5 vezes mais energia em relação à média mundial, enquanto que os africanos menos da metade. Os brasileiros e chineses ficaram próximos da média. Em 1970, a América do Norte e a Europa-Eurásia foram responsáveis por $80 \%$ da energia primária, contra $47 \%$, em 2011, demonstrando uma queda na participação no consumo primário mundial, por conta do crescimento populacional em outras regiões. No Oriente Médio e na África, apesar da participação do consumo mundial de energia não ultrapassar um dígito, observa-se um avanço significativo destas regiões, passando de $2 \%$, em 1970 , para $6 \%$, em 2011 , no Oriente Médio e de $1 \%$ para $3 \%$, de 1970 para 2011, na África. Em 2011, observa-se um aumento de 25 pontos percentuais no consumo energético dos países da Ásia-Pacífico. A Europa-Euroásia, a América do Norte e a Ásia-Pacífico responderam, em 2011 , por $86 \%$ da energia primária consumida no mundo (BP, 2012).

Outro dado importante diz respeito à evolução do consumo e à oferta total de energia primária no mundo. O consumo e a oferta aumentaram ao longo do tempo, conforme pode ser observado na Figura 1. No período que o compreende 1980-2009, percebe-se a evolução positiva no consumo total mundial de energia primária.

Ao comparar os anos 1980 e 2009 , o consumo mundial teve um incremento de $78 \%$, passando de 7.333 milhões de tep para 12.697 milhões de tep. A variação média no crescimento do consumo energético mundial foi de $1,96 \%$ a.a. e para a oferta mundial de energia foi de $1,83 \%$ a.a.. A oferta de energia passou de 7.241 para 12.201 milhões de tep, representando um incremento de $68,49 \%$. Este aumento pode ser explicado, em parte, pelo crescimento da população mundial, que aumentou em $52,24 \%$, de 1980 para 2009 , com uma variação média anual de $2,02 \%$. Junto ao crescimento populacional, destaca-se o grau do crescimento econômico mundial que no período de 1980 a 2009, foi em média 2,8\% a.a., segundo World Bank (2013). A Figura 2 apresenta a evolução do consumo mundial de energia primária, segundo regiões selecionadas.

A América do Norte teve uma variação de
$27,50 \%$, enquanto que as regiões que mais cresceram foram o Oriente Médio, com uma variação de $387,57 \%$, e a Ásia-Pacífico, com $264,81 \%$, as quais também tiveram as maiores variações médias anuais no consumo energético total com $5,45 \%$ e $4,43 \%$, respectivamente. O crescimento da região Ásia-Pacífico pode ser explicada, em parte, pelo crescimento populacional da China, nos últimos anos, o que justificaria o comportamento de crescimento exponencial observado na Figura 2. A África apresentou um crescimento médio anual de $3,20 \%$ e uma variação de $154,68 \%$ no consumo energético, dialogando com o aumento significativo da população para o mesmo período. A América do Norte e a Europa-Euroásia cresceram, em média ao ano, $0,84 \%$ e $0,13 \%$, respectivamente. América do Sul e Central tiveram um crescimento de $131 \%$. Em termos de produção mundial de energia primária, a Tabela 3 apresenta dados de variação percentual (BP, 2012).

Ao longo do tempo, não foi apenas o montante do consumo e a produção que mudaram, a composição da matriz energética mundial também sofreu alterações. Pode-se observar, na Tabela 4, a alteração na participação das fontes primárias de energia.

Em 1970, o consumo de fontes não renováveis (petróleo, carvão mineral, gás natural e energia nuclear) representou $94 \%$ do total de energia consumida e, em 2011, este percentual foi de $92 \%$. No que tange às fontes energéticas de origem fósseis, estas ainda continuam a ser majoritariamente utilizadas no mundo, correspondendo por $87 \%$ do consumo mundial. Em 2011, mesmo com uma redução da participação do petróleo em 13 pontos percentuais, em relação a 1970, as fontes renováveis ainda apresentam uma participação pequena, passando de $6 \%$ para 8\%. Em 1970, a energia hidráulica foi responsável por apenas $5 \%$ do consumo mundial de energia e, em 2011, por $6 \%$.

Em termos setoriais, o setor industrial respondeu pela maior participação no consumo energético mundial em 2011, com $38 \%$, seguido do setor de transportes, com $19 \%$. O setor residencial é o terceiro em termos de consumo energético, com $10 \%$ do total, e o setor comercial responde por $6 \%$ do consumo mundial de energia. Há, ainda, $27 \%$ do consumo total de energia no mundo ocasionado por perdas de eletricidade relacionadas (EIA, 2012b).

\subsection{OFERTA E DEMANDA DE ENERGIA NO BRASIL}




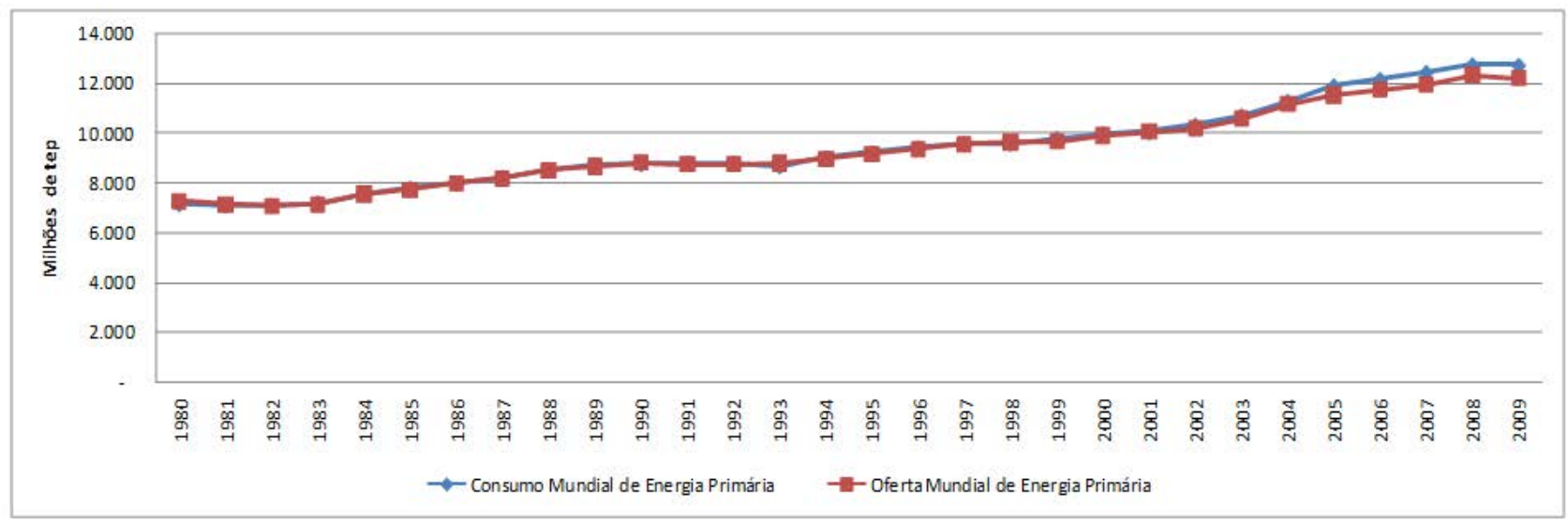

Figura 1 - Evolução do consumo e oferta total mundial de energia para o período de 1980 a 2009

Fonte: Elaboração própria a partir de EIA (2012b).

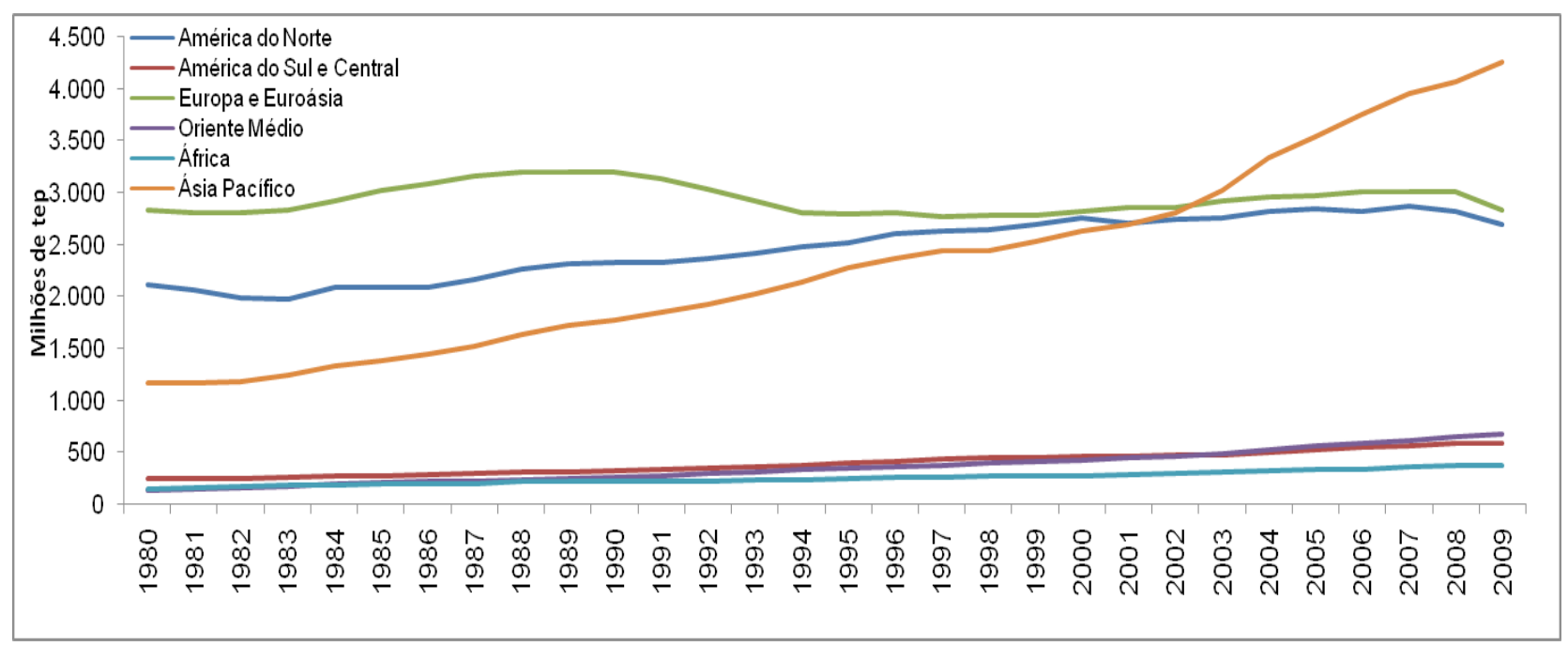

Figura 2 - Evolução do consumo mundial total de energia, por regiões, para o período de 1980 a 2009 Fonte: Elaboração própria a partir de BP (2012).

Tabela 3 - Produção mundial de energia primária por região mundial para o período 1980 a 2009

\begin{tabular}{ccc}
\hline Região Mundial & Variação anual (1980-2009)(\%) & Variação de 1980 para 2009 (\%) \\
\hline América do Norte & 0,64 & 19,63 \\
América Central e do Sul & 3,17 & 144,25 \\
Europa & 0,40 & 11,15 \\
Euroásia & 0,63 & 17,02 \\
Oriente médio & 1,84 & 56,70 \\
África & 2,63 & 107,67 \\
Ásia-Pacífico & 4,91 & 296,90 \\
Mundo & 1,83 & 68,49 \\
\hline
\end{tabular}

Fonte: Elaboração própria a partir de EIA (2012b). 
Tabela 4 - Composição do consumo da matriz energética mundial, por fonte de energia primária, para os anos de 1970 e 2011

\begin{tabular}{ccc}
\hline Fonte de Energia Primária & $1970(\%)$ & $2011(\%)$ \\
\hline Petróleo & 46 & 33 \\
Gás Natural & 18 & 24 \\
Carvão & 30 & 30 \\
Energia Nuclear & 0 & 5 \\
Hidroeletricidade & 5 & 6 \\
Renováveis (*) & 1 & 2 \\
\hline
\end{tabular}

Fonte: Elaboração própria a partir de BP (2012).

Nota: (*) Dados das fontes renováveis são de 1990 e 2011. Não foram encontrados dados equivalentes aos dos anos de 2011 para 1970. Assim, optou-se pelo valor mais próximo de 1970.

Em 2011, para cada mil dólares produzidos no Brasil foram consumidas cerca de $11,78 \%$ de toda energia ofertada internamente. A oferta interna de energia foi de 272,4 milhões de tep para produzir um Produto Interno Bruto (PIB) na ordem de US\$ 2.312 bilhões. A energia consumida foi de 257,8 milhões de tep. Cada brasileiro consumiu, em média, 1,41 tep no mesmo ano, enquanto que, em 2001, este consumo foi de 1,3 tep/habitante. O setor de transformação de energia foi o que mais a utilizou, com $72 \%$ de participação no dispêndio de 2011, enquanto que o consumo final respondeu por $28 \%$ (BRASIL, 2013).

A matriz energética brasileira é considera uma das mais limpas do mundo, em razão da forte presença de fontes renováveis de energia, como a geração de eletricidade a partir de fontes hidráulicas, lenha, produtos da cana de açúcar e outras fontes renováveis. A partir da Tabela 5, procura-se comparar o consumo de energias primárias do Brasil com o consumo mundial em 2011.

No Brasil, a energia primária renovável respondeu por $40 \%$ do consumo total, contra $8 \%$ no mundo. Contudo, o consumo de petróleo no país é 12 pontos percentuais maiores que o consumo mundial, representando $45 \%$ das fontes primárias consumidas no mesmo ano. Em termos do total das fontes de energia não renováveis (petróleo, energia nuclear, gás natural e carvão), o Brasil somou $60 \%$ do total de energia primária. Isso demonstra uma forte inclinação dopaís para a utilização de fontes renováveis de energia.

Ao longo dos anos, a matriz energética nacional também sofreu transformações. Em 1940, a lenha e o carvão vegetal representavam 83,34\% das fontes energéticas consumidas pela população, enquanto que, em 2011, não chegou a $10 \%$. Os produtos da cana-de-açúcar, em 2011, representaram quase $16 \%$, contra $2,37 \%$, em 1940 . O petróleo, seus derivados e o gás natural passaram de $6,41 \%$, em 1940, para 48,76\%, em 2011 (BRASIL, 2013). A Figura 3 apresenta a evolução do consumo final de energia por fonte, considerando a última década.

As fontes renováveis (lenha, bagaço decana, álcool etílico, eletricidade, carvão vegetal e outras renováveis) representaram, em 2011, 43,59\% do consumo nacional de energia. As renováveis que tiveram maior participação foram a eletricidade, com $17 \%$, o bagaço da cana, com $11 \%$, enquanto o álcool etílico foi responsável por $5 \%$ do consumo brasileiro de 2011. Em relação à variação de 2001

Tabela 5 - Comparação do consumo de fontes primárias de energia entre o Brasil e o mundo em 2011

\begin{tabular}{ccc}
\hline Fonte de Energia Primária & Brasil (\%) & Mundo (\%) \\
\hline Petróleo & 45 & 33 \\
Gás Natural & 9 & 24 \\
Carvão Mineral & 5 & 30 \\
Energia Nuclear & 1 & 5 \\
Hidroeletricidade & 37 & 6 \\
Renováveis (*) & 3 & 2 \\
\hline
\end{tabular}

Fonte: Elaboração própria a partir de BP (2012). 


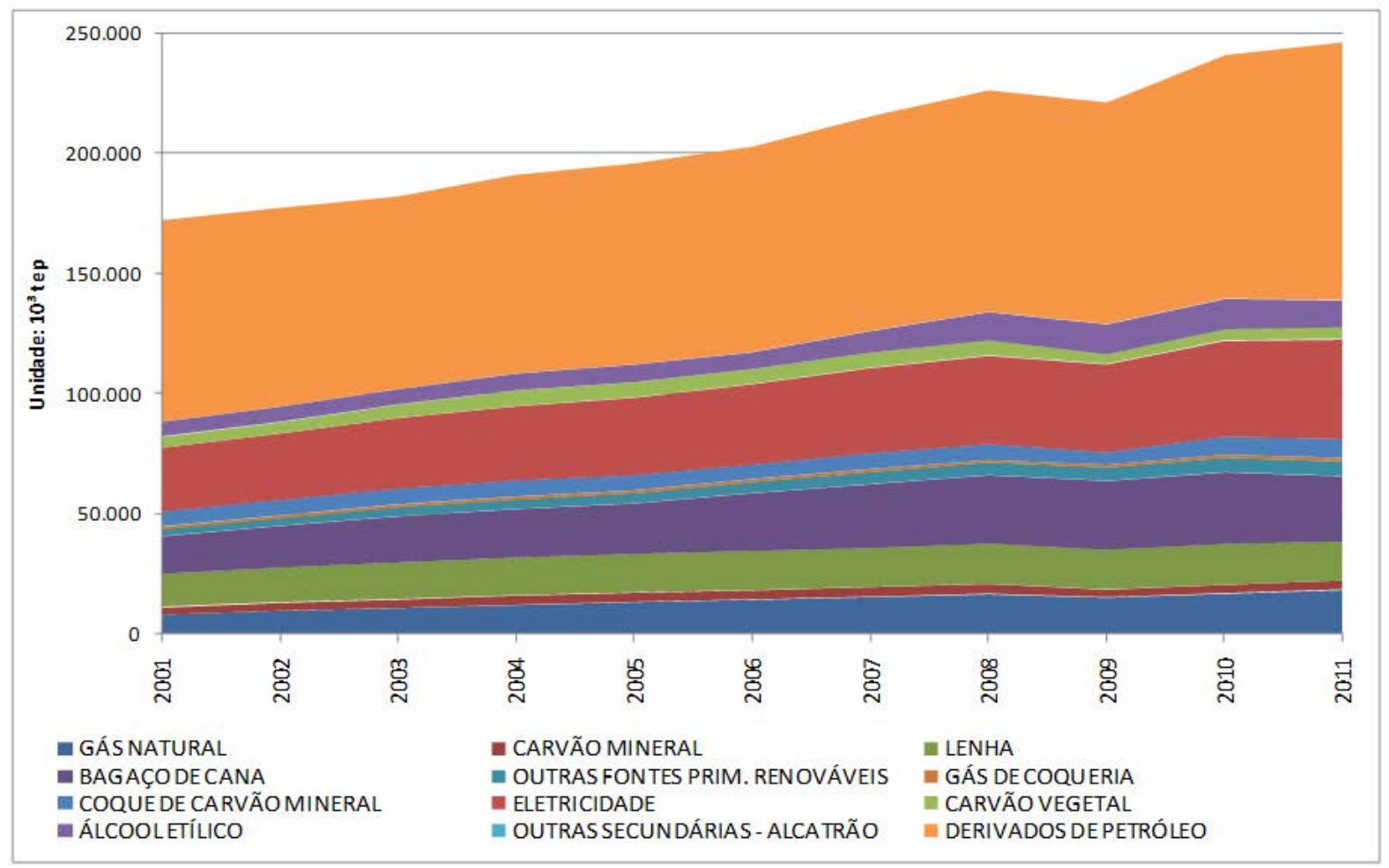

Figura 3 - Evolução do consumo final por fonte para o período de 2001 a 2011 no Brasil Fonte: Elaboração própria a partir de Brasil (2013).

para 2011, o álcool etílico apresentou um incremento de $86 \%$, passando de $6.05210^{3}$ tep, em 2001, para $12.62810^{3}$ tep, em 2011. De todas as fontes consumidas, as únicas que apresentaram uma variação negativa foram o gás canalizado, que teve um consumo de $3510^{3}$ tep, em 2001, e não registrou consumo em 2011; e o óleo combustível, que teve a maior variação negativa, passando de 8.469 , em 2001, para $4.60510^{3}$ tep, em 2011, ou seja, um decréscimo de $46 \%$ no consumo final (BRASIL, 2013).

No que se refere à oferta interna de energia, do total ofertado em 2011 (272.348 10³ tep),
$56 \%$ foram de fonte não renováveis, destacando o petróleo, que foi responsável por $38,63 \%$ do total ofertado e $69 \%$ do total das fontes não renováveis. As fontes renováveis responderam pelos outros $44 \%$ de oferta interna, sendo que os produtos derivados da cana, somados com a energia hidráulica e elétrica somaram $30 \%$ na oferta global e foram ressáveis por $98 \%$ de toda oferta de energia renovável. Neste sentido, a Tabela 6 traz uma média da oferta interna de energia paras as últimas cinco décadas das principais fontes energéticas.

Os dados revelam que petróleo, derivados e gás natural aumentaram três vezes mais na

Tabela 6 - Média da oferta interna de energia por década em $10^{3}$ tep no período de 1970 a 2010 no Brasil

\begin{tabular}{cc}
\hline Recursos Energéticos & $(\%)$ \\
\hline Óleo Diesel & 48,79 \\
Óleo Combustível & 1,31 \\
Gasolina Automotiva & 28,04 \\
Querosene & 4,79 \\
Álcool Etílico & 14,46 \\
Outras & 2.61 \\
\hline
\end{tabular}

Fone: Brasil (2013).

Nota: $\left(^{*}\right)$ Média dos dois anos disponíveis para esta década: 2010 e 2011. (**) Inclui Outras Fontes Primárias Renováveis e Urânio. 


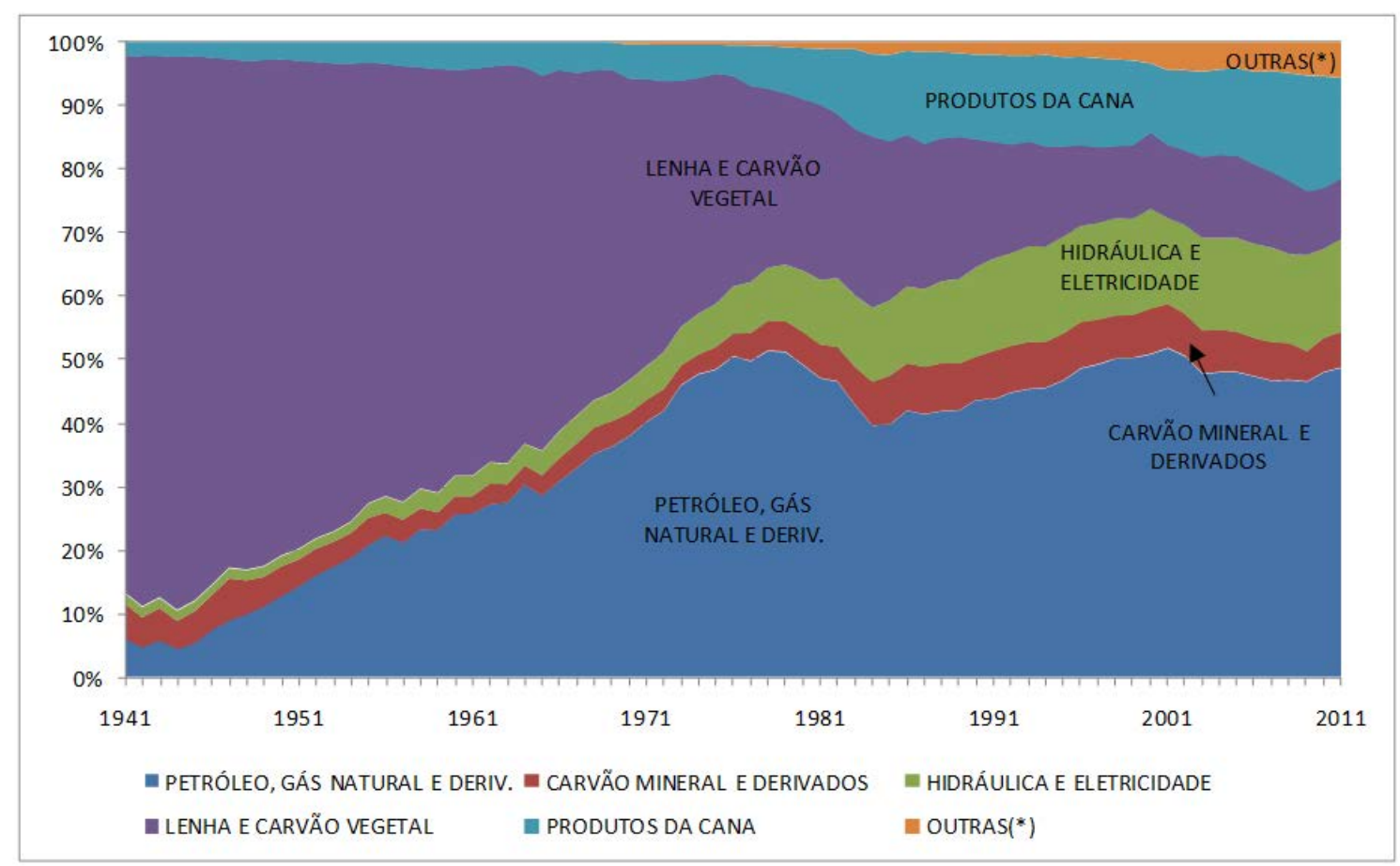

Figura 4 - Participação por fonte na oferta interna de energia por década no período 1940 a 2011 no Brasil Fonte: Brasil (2013).

Nota: $\left({ }^{*}\right)$ Outras fontes renováveis.

década de 2010 em relação a 1970. Os produtos derivados da cana-de-açúcar aumentaram oito vezes. Percebe-se um salto na oferta de produtos da cana da década de 1970 para 1980, passando de $5.14810^{3}$ tep para $15.64610^{3}$ tep. Esse aumento deve-se à implantação do Programa Pró Álcool, o qual dá início a uma série de incentivos para a produção de etanol, a fim de se obter um combustível alternativo ao petróleo e seus derivados, motivado pelas crises do petróleo na década de 1970. Para finalizar, em relação às questões relacionadas ao consumo e oferta nacional agregados, apresenta-se a evolução da matriz energética no que se refere à oferta interna de energia. A Figura 4 mostra a mudança na matriz energética brasileira ao longo do tempo, tomando como base o período de 1940 até 2010.

A Figura 4 apresenta a transição do carvão vege- cipais energéticos para o uso predominante de petróleo, derivados e gás natural. Além disso, percebe-se a introdução e aumento dos produtos de cana a partir de meados da década de 1970, demonstrando uma substituição da lenha e carvão vegetal por tais produtos. Esta substituição se dá com a implantação do Pró Álcool, em 1974, no Brasil, como resposta à primeira crise do petróleo no início dos anos de 1970. A oferta de energia hidráulica e eletricidade também aumentam a partir dos anos de 1970, chegando, nos anos 2000, com forte participação e presença conforme já relatado.

Apresentada a oferta e o consumo de energia de forma geral e agregada, passa-se ao consumo de etanol (álcool etílico). O consumo de álcool etílico apresentou uma variação anual média de $8 \%$ e teve uma um aumento de $101 \%$ de $2001 \mathrm{em}$ relação a 2011, passando de $10.26510^{3} \mathrm{~m}^{3}$ para

Tabela 7 - Consumo brasileiro de recursos energéticos para o setor de transportes em 2011

\begin{tabular}{cc}
\hline Recursos Energéticos & $(\%)$ \\
\hline Óleo Diesel & 48,79 \\
Oleo Combustivel & 1,31 \\
Gasolina Automotiva & 28,04 \\
Querosene & 4,79 \\
Álcool Etilico & 14,46 \\
Outras & 2.61 \\
\hline
\end{tabular}

Fonte: Elaboração própria a partir de Brasil (2013). 


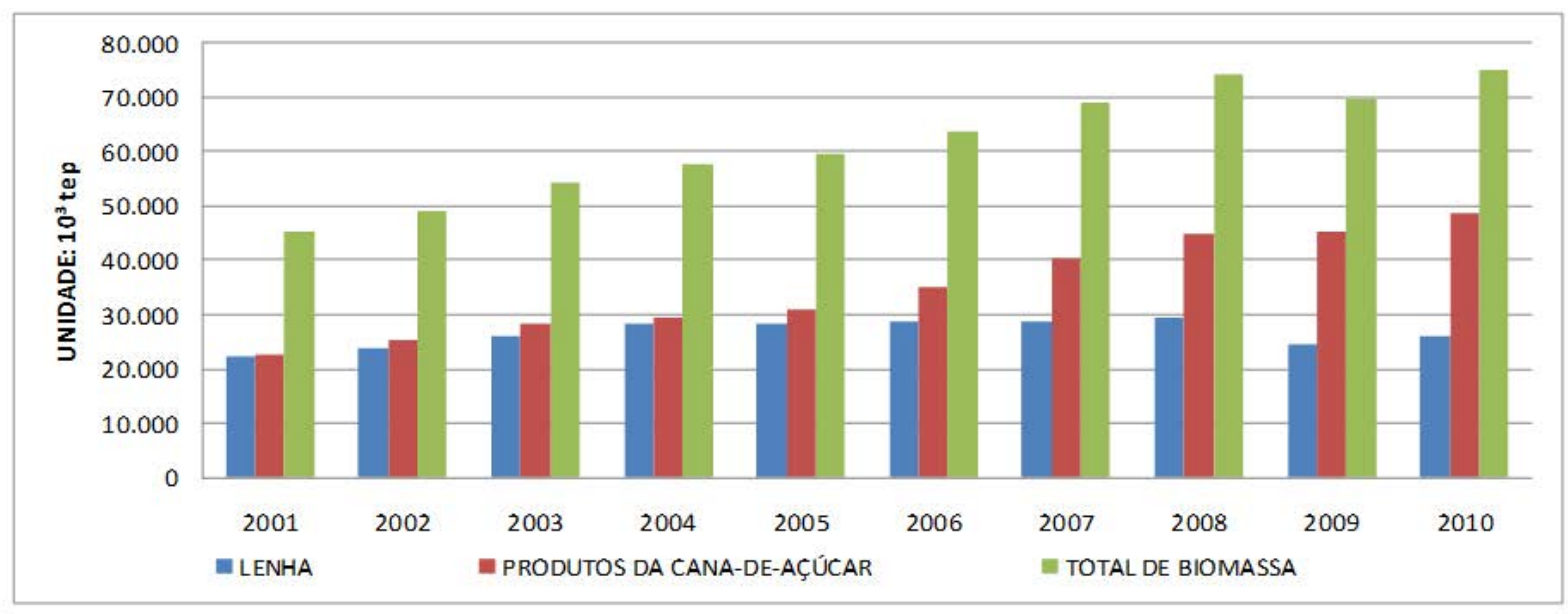

Figura 5 - Produção de energia primária: produtos da cana de açúcar, lenha e total de biomassa, para o período de 2001 a 2010 no Brasil

Fonte: Elaboração própria a partir de Brasil (2013).

$20.6510^{3} \mathrm{~m}^{3}$. O setor de transporte rodoviário consome todo o etanol produzido, tanto o hidratado quanto o anidro, e respondeu por $0,67 \%$ de toda energia consumida no país. A Tabela 7 apresenta 0 consumo total do setor de transporte por recursos energético em 2011.

Os combustíveis fósseis representam o maior consumo no setor de transportes, com $82,3 \%$. Dentre estes, o óleo diesel é o mais utilizado, respondendo por $48,79 \%$. O etanol teve uma participação de $14,46 \%$ no consumo de energéticos no setor de transportes em 2011.

No Brasil, as principais biomassas utilizadas como recursos energéticos são os produtos da cana e a lenha. Os produtos primários da cana são o "o caldo da cana, melaço, bagaço, pontas, folhas e olhaduras, e como produtos secundários o álcool anidro e hidratado" (EPE, 2011, p.191). A produção do caldo de cana e do melaço somou, em 2010, $202.54510^{3}$ tep e foram consumidos totalmente pelo setor de transformação ${ }^{3}$ para a produção de álcool etílico. Já o bagaço da cana,

com um consumo total de $158.27110^{3}$ tep, no mesmo ano, foi absorvido pelo setor de transformação para geração de energia elétrica (12.752 10³ tep) e consumido pelos setores energético ${ }^{4}\left(61.84310^{3}\right.$ tep) e industrial (83.676 $10^{3}$ tep) (BRASIL, 2013).

Em 2010, a produção total de lenha foi de

3 "O Setor Transformação agrupa todos os centros de transformação onde a energia que entra (primária e/ou secundária) se transforma em uma ou mais formas de energia secundária com suas correspondentes perdas na transformação" (EPE, 2011, p.181).

4 Setor energético: "Energia consumida nos Centros de Transformação e/ou nos processos de extração e transporte interno de Produtos Energéticos, na sua forma final" (EPE, 2011, p.182).
$84.10110^{3}$ tep, onde aproximadamente, 34,5\% foram destinadas à produção de carvão vegetal e geração de energia elétrica. Os outros $65,5 \%$ tiveram uso final energético nos setores residencial, comercial, agropecuário e industrial. Os setores residencial e industrial responderam por $84,7 \%$ da lenha com uso final energético, sendo responsáveis quase nas mesmas proporções, $42,7 \%$ (residencial) e $42 \%$ (industrial) (BRASIL, 2013). Neste sentido, apresenta-se, na Figura 5, a evolução da produção brasileira de energia primária de produtos de cana e lenha e total de biomassa para o período de 2001 a 2010.

No período apresentado, a produção primária de produtos da cana supera a de lenha e, a partir de 2006, a distância na produção se acentua. Os produtos da cana apresentaram um crescimento médio de $9,5 \%$ a.a., ao passo que a lenha cresce, em média, 1,5\% a.a.. Em 2009, a produção de lenha caiu $15,9 \%$ e a de cana cresceu $0,5 \%$, resultados que podem ser justificados pela crise mundial de 2008. Percebe-se que o aumento da produção primária de biomassa é resultado do incremento dos produtos da cana que, em 2001, eram responsáveis por $50,40 \%$ do total de biomassa e a lenha por $49,60 \%$. Já em 2010 , a lenha respondeu por $34,80 \%$ do total da biomassa e a cana por $65,20 \%$. A variação percentual do total de biomassa de 2001 para 2010 foi de $65,62 \%$ e dos produtos da cana de açúcar foi de $114,26 \%$, para o mesmo período. Destaca-se, ainda, que a biomassa foi responsável por $29,55 \%$ do total de energia consumida no Brasil e os produtos da cana de açúcar por 19,27\%, demonstrando, assim, a sua importância (BRASIL, 2013). 
Isto posto, a seção que segue aborda os cenários futuros e perspectivas para o consumo de energia. Estes cenários são apontados por alguns estudos realizados por órgãos como o Ministério de Minas e Energia (MME) e a EIA, entre outros, sobre perspectivas futuras em um horizonte de 20 a 30 anos.

\section{CENÁRIOS FUTUROS PARA OFERTA E CONSUMO DE ENERGIA}

O EIA publicou, em 2011, o International Energy Outlook 2011, o qual traz uma estimativa das perspectivas do consumo de energia para os mercados internacionais para até 2035 . O estudo incluiu cinco cenários: 1) casos de referência; 2) caso de alta do petróleo; 3) caso baixa do preço do petróleo; 4) caso tradicional alta do petróleo; e 5) tradicional baixa do preço do petróleo (EIA, 2011). Neste artigo apresentam-se as descrições dos cenários 1,2 e $3^{5}$. Para o cenário de casos de referência, os preços mundiais do petróleo estão projetados em US\$ 95,00 por barril, em 2015, aumentando lentamente para US\$125,00 por barril, em 2035. Este cenário é considerado o melhor em relação aos custos de exploração e desenvolvimento e de acesso aos recursos do petróleo fora dos EUA. Neste cenário, os países membros da Organização dos Países Exportadores de Petróleo (OPEP) irão manter a atual participação no mercado internacional do petróleo, buscando realizar investimentos futuros para o aumento da capacidade produtiva de petróleo, a fim de responderem por $42 \%$ da produção mundial de combustíveis líquidos. Para isso, a produção deverá aumentar em 11,3 milhões de barris por dia, no período de 2008 a 2035.

Para o cenário de casos com alta dos preços do petróleo, os preços mundiais estão projetados em US\$200,00 por barril, em 2035. A elevação dos preços neste cenário se dá por: 1) um aumento na demanda externa de combustíveis líquidos para países não membros da Organização para a Cooperação e Desenvolvimento Econômico (OCDE), devido a um crescimento econômico, com taxas maiores em 1,0 ponto percentual, maior que em relação ao caso de referência; e 2) uma redução da oferta, gerada por suposições de que diversos produtores não membros da OPEP irão restringir ainda mais o acesso, ou aumentar os impostos sobre áreas potenciais de produção e que os países

5 A descrição dos demais cenários pode ser obtida em EIA (2011). membros reduzirão a produção, substancialmente, abaixo dos níveis atuais. Com o preço do petróleo em alta, há um incentivo na produção de combustíveis líquidos não convencionais em relação aos casos de referência.

Ao contrário de um cenário com preços elevados do petróleo, o cenário com preços baixos se dá devido a uma diminuição da demanda de combustíveis por parte de países não membros da OCDE e um deslocamento na curva de oferta para cima. O aumento da oferta é reflexo de maior acesso e regimes fiscais mais atraentes, em áreas potenciais de países não membros da OCDE, bem como níveis mais elevados de produção dos membros da OPEP. A retração da demanda é ocasionada por uma redução de 1,5 pontos percentuais da taxa de crescimento em relação ao caso de referência de países não membros da OCDE.

Segundo EIA (2011), espera-se que, em 2020, o consumo mundial de energia chegue a 505 quadrilhões de BTUs e, em 2035, a 770 quadrilhões de BTUs. Isso significa um incremento na ordem de $53 \%$ para o período. Para o caso de referência, é esperado um aumento do consumo energético tanto para países membros como não membros da OCDE. Os países asiáticos não membros da OCDE têm o maior aumento projetado, $117 \%$, de 2008 para 2035. A América Central e do Sul também apresentam crescimento do consumo de energia primária acima do patamar mundial, na ordem $73 \%$, passando de 28 para 48 quadrilhões de BTUs. Ao passo que o consumo dos países membros da OCDE cresce com uma taxa de $0,6 \%$ em média ao ano, para os países não membros, esta mesma taxa apresenta-se maior, 2,3\% ao ano. A Figura 6 apresenta a evolução da projeção do consumo mundial de energia para o período de 2015 a 2035.

Ao analisar o período projetado na Figura 6, o consumo mundial de energia passa de 573 quadrilhões de BTUs, em 2015, para os 770 quadrilhões de BTUs, em 2035, apresentando um crescimento de $34 \%$. O consumo total dos países não membros da OCDE apresenta-se maior em todo período projetado em relação aos países membros, com crescimento de $117 \%$. Em 2020, os países não membros da OCDE consomem 38\% a mais de energia que países membros e, em 2035, este percentual sobe para $67 \%$.

O crescimento no consumo mundial de energia primária é baseado na expectativa da retomada do crescimento econômico e da expansão da população mundial. Para o caso de referência, o PIB mundial deverá crescer $3,4 \%$ ao ano, no período de 2008-2038. A mesma taxa média anual para membros da OCDE é de 2,1\%. Enquanto que, 


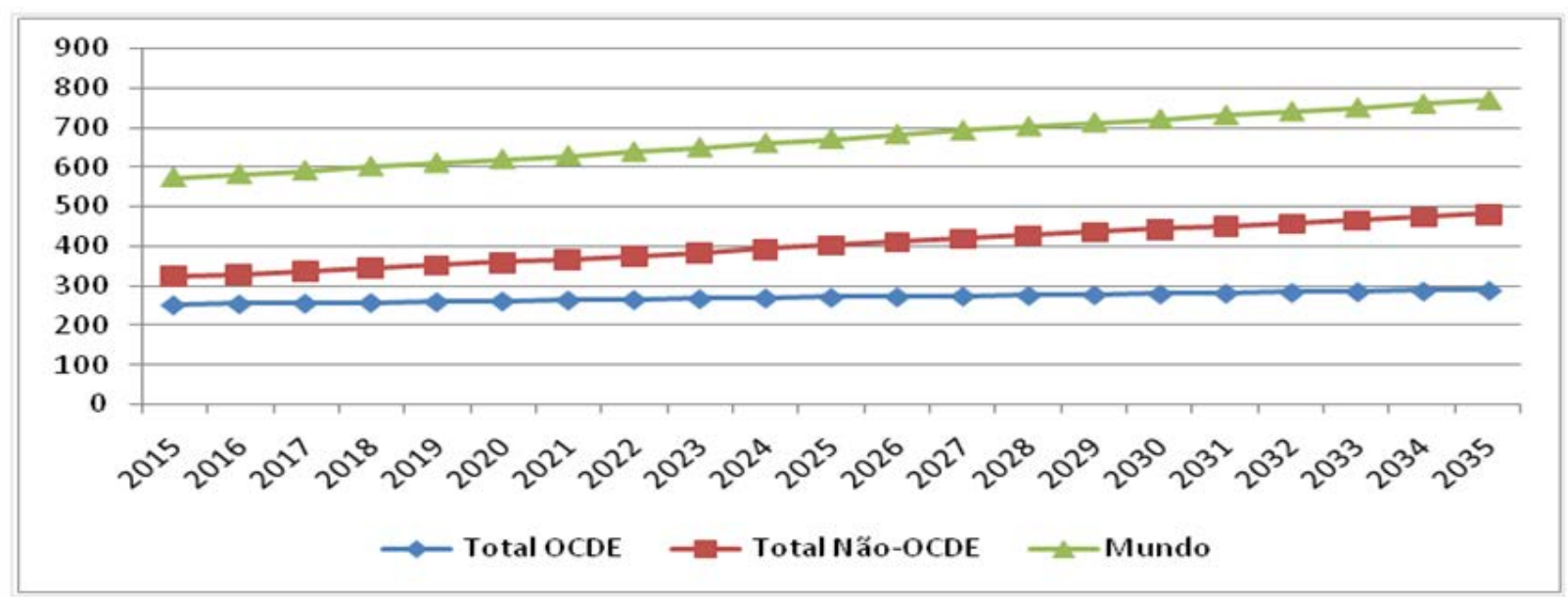

Figura 6 - Projeção do consumo mundial de energias primárias para o período de 2015 a 2035

Fonte: Elaboração própria a partir de EIA (2012b).

para países não membros, o PIB cresce acima da taxa mundial, 4,6\%. Os países não membros da OCDE devem ser responsáveis pelo incremento na demanda do consumo energético mundial, esperado por um forte crescimento econômico de longo prazo. Este incremento é projetado em $85 \%$ para países não membros da OCDE, enquanto que para os países membros é esperado um aumento de apenas 18\%, para o caso de referência (EIA, 2011).

Contudo, há uma preocupação com a recuperação e estabilidade econômica frente à crise de 2008 dos países membros da OCDE e que tal recuperação não deva acompanhar taxas de crescimento altas, como ocorreu em momentos anteriores. Entretanto, as economias emergentes continuam a ter crescimentos elevados, em parte, dado às fortes entradas de capitais e aos elevados preços das commodities. Contudo, pressões de inflação e a necessidade de reequilíbrio do comércio externo são apontadas como preocupações particulares de importantes economias em desenvolvimento (EIA, 2011).

No que se refere ao setor de transporte, este responde pela maior parte do crescimento total do uso de combustíveis líquidos, no período projetado. Sua participação aumentou de 54\%, em 2008 , para $60 \%$, em 2035 , no consumo total. Este aumento parte do pressuposto de que não haja avanços tecnológicos significativos. Para países não membros da OCDE, deve aumentar a participação do setor de transportes no consumo de combustíveis líquidos, em média, 2,6\%, e para países membros, $0,3 \%$. Assim, os combustíveis líquidos continuam a fornecer a maior parte da energia consumida. Apesar do aumento dos preços dos combustíveis, o uso de combustíveis líquidos para o setor de transportes aumenta, em média, ao ano, $1,4 \%$, ou um total de $46 \%$ no período de 2008 a 2035 . Este setor representa $82 \%$ do total do aumento do consumo de combustíveis líquidos no período de 2008 a 2035, os outros $18 \%$ estão relacionados ao setor industrial. Em contraponto, nos demais setores de uso final e geração de energia elétrica, a sua utilização diminui (EIA, 2011).

No longo prazo, está projetado um aumento no consumo mundial de energia de todas as fontes de combustíveis até 2035. A projeção da produção de petróleo e de outros líquidos é na ordem de 96,6 milhões de barris por dia, em 2020, e de 112,20 milhões de barris por dia, para 2035. A produção de combustíveis líquidos (tanto convencionais, quanto não convencionais) aumenta em um total de 26,6 milhões de barris por dia de 2008 para 2035 (EIA, 2011). Isto posto, a Figura 7 mostra o cenário mundial de crescimento dos recursos energéticos para o período de 2015 a 2035 para o caso de referência.

Em termos de projeção, os recursos não convencionais (incluindo biocombustíveis, óleo de xisto e outros) tanto para países membros como não membros da OPEP, crescem em média $4,6 \%$ ao ano ao longo do período de projeção. Ao considerar que os altos preços do petróleo sejam sustentados, os recursos não convencionais podem tornar-se economicamente competitivos, especialmente quando restrições geopolíticas ou outras limitem o acesso aos futuros recursos convencionais (EIA, 2011).

A produção mundial de combustíveis líquidos não convencionais, que totalizaram apenas 3,9 milhões de barris por dia, em 2008, aumenta para 13,1 milhões de barris por dia e é responsável 


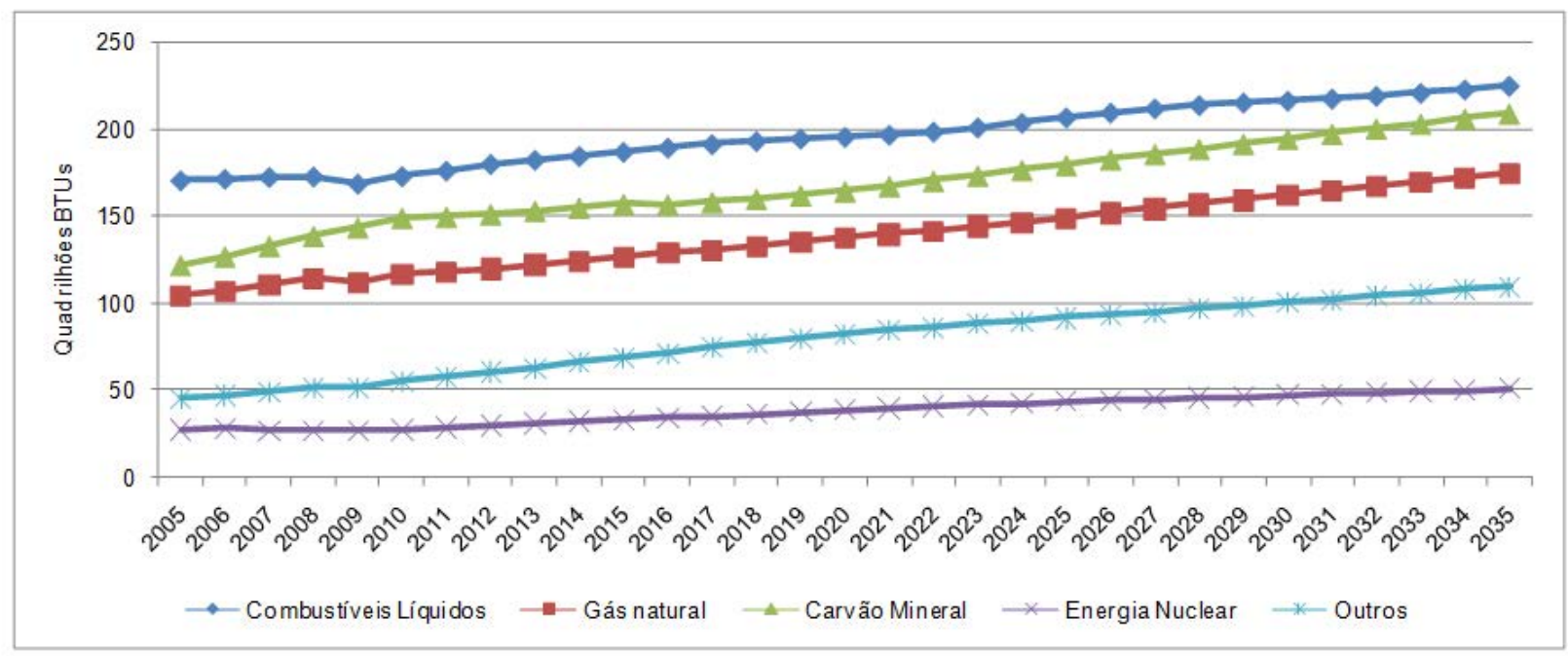

Figura 7 - Evolução do consumo mundial de energia para o período de 2015 a 2035, no caso de referência Fonte: Elaboração própria a partir de EIA (2012b).

por $12 \%$ da oferta mundial total de líquidos em 2035. Os maiores componentes de produção não convencional futuro são 4,8 milhões de barris por dia de petróleo canadense, 2,2 e 1,7 milhões de barris por dia de biocombustíveis dos EUA e do Brasil, respectivamente, e de 1,4 milhões de barris por dia de petróleo extrapesado venezuelano. Esses quatro combustíveis líquidos não convencionais representam quase $3 / 4$ do aumento ao longo do período de projeção (EIA, 2011).

\section{I CENÁRIOS FUTUROS PARA OFERTA E CONSUMO DE ENERGIA NO BRASIL}

O MME elaborou o Plano Nacional de Energia 2030 (PNE 2030), composto por uma série de estudos temáticos, os quais formam a base para a elaboração do relatório final. Para este artigo, utilizou-se com maior frequência o PNE 2030: combustíveis líquidos e relatório final. O Plano traça projeções de consumo e produção dos recursos energéticos no país. Foram elaborados seis cenários ao todo, contudo, quatro cenários nacionais foram analisados nos documentos, a saber: 1) Cenário A: "Na crista da onda"; 2) Cenário B1: "Surfando a marola"; 3) Cenário B2: "Pedalinho"; e 4) Cenário C: "Náufrago". Para o estabelecimento das estratégias de expansão do sistema nacional energético, o Cenário B1 foi priorizado. A escolha de tais cenários justifica-se pela difícil previsão da eficácia na gestão dos problemas domésticos no horizonte de até 2030 (BRASIL, 2007).

Neste sentido, o PNE 2030 aponta para um crescimento do consumo de energia final, acompanhando as projeções internacionais. No pior cenário, o consumo de energia final, no Brasil, passa de $161,810^{6}$ tep (2005) para 309,3 $10^{6}$ tep (2030), um aumento de $91 \%$. E para o melhor cenário, o consumo de energia final pode chegar a $47710^{6}$ tep, em 2030, comparado a 2005, refletindo um aumento de $19 \%$. O crescimento demográfico projetado para 2030 aponta uma população de 238,5 milhões de habitantes. Ao considerar a oferta interna de energia, o consumo médio de energia por habitante pode chegar a 2,33 tep/ano, em 2030 (BRASIL, 2007). A Tabela 8 apresenta os dados de oferta interna de energia, projetados para os anos de 2020 e 2030.

As energias renováveis devem responder por $46,6 \%$ da oferta interna de energia, cerca de 2,5 pontos percentuais a mais que em 2011. Os produtos da cana de açúcar devem representar, em $2030,18,5 \%$ da oferta interna de energia, também 2,5 pontos percentuais a mais que em 2011, quando foi de $16 \%$. Por outro lado, a participação do petróleo na matriz energética deve diminuir, respondendo por $28 \%$ de toda oferta interna de energia, contra $38 \%$ em 2011.

No que tange aos combustíveis líquidos (etanol, óleo diesel, gasolina, óleo combustível, GLP, querosene, nafta), o setor de transporte é o que apresenta maior demanda por tais combustíveis. A demanda de combustíveis líquidos pelo setor de transportes fica entorno de $75 \%$ por ano. $\mathrm{Na}$ Tabela 9 verifica-se a demanda para os anos selecionados.

O setor de transportes é o responsável pelo maior consumo de combustíveis líquidos em todos os anos projetados, chegando a representar $77 \%$ do total de líquidos em 2030. Os menores consumidores de combustíveis líquidos são os setores 
Tabela 8 - Oferta interna de energia em $10^{3}$ tep proietados para os anos de 2020 e 2030

\begin{tabular}{ccc}
\hline Identificação & 2020 & 2030 \\
\hline Energia não renovável & 216.007 & 297.786 \\
Petróleo e derivados & 119.136 & 155.907 \\
Gás natural & 56.136 & 86.531 \\
Carvão mineral e derivados & 30.202 & 38.404 \\
Urânio (u3o8) e derivados & 9.976 & 16.944 \\
Energia renovável & 182.430 & 259.347 \\
Hidráulica e eletricidade & 54.551 & 75.067 \\
Lenha e carvão vegetal & 28.069 & 30.693 \\
Derivados da cana de açúcar & 69.475 & 103.026 \\
Outras renováveis & 30.335 & 50.561 \\
Total & 298.437 & 557.133 \\
\hline
\end{tabular}

Fonte: Brasil (2007).

Tabela 9 - Evolução da demanda de combustíveis líquidos por setor (mil tep) entre 2015 e 2030

\begin{tabular}{ccccc}
\hline Setor da Economia & 2015 & 2020 & 2025 & 2030 \\
\hline Setor industrial & 6.756 & 8.004 & 9.863 & 11.196 \\
Setor comercial & 624 & 737 & 1021 & 1.225 \\
Setor público & 759 & 901 & 1277 & 1.556 \\
Setor de transportes & 62.984 & 77.340 & 1081.18 & 132.636 \\
Setor agropecuário & 6.521 & 8.652 & 12.251 & 15.000 \\
Setor residencial & 6.270 & 8.268 & 10.508 & 11.406 \\
Total & 83.914 & 103.902 & 143.038 & 173.019 \\
\hline
\end{tabular}

Fonte: Brasil (2007).

comercial e público, respondendo em todos os anos por $1 \%$ da demanda total cada setor.

\section{PERSPECTIVAS MUNDIAIS E NACIONAIS PARA O ETANOL}

O consumo mundial de biocombustíveis, em 2011, foi da ordem de 104 milhões de $\mathrm{m}^{3}$. O Brasil foi responsável por $20,74 \%$ do consumo mundial total, ficando atrás, somente, dos EUA, que, por sua vez, participaram com $49,39 \%$ do consumo mundial de biocombustíveis. No que se refere ao consumo de etanol, o mundo consumiu, em 2011, aproximadamente, 80,5 milhões de $\mathrm{m}^{3}$, cerca de $77 \%$ do total de biocombustíveis (EIA, 2012b). O Brasil e os EUA são os maiores consumidores de etanol. Neste sentido, apresenta-se a Tabela $10 \mathrm{com}$ dados dos dez maiores consumidores de etanol no mundo, em 2011, e a relação na participação do consumo mundial de biocombustíveis.

Os 10 maiores consumidores de etanol somaram 76,11 milhões de $\mathrm{m}^{3}$, cerca de $94 \%$ do consumo mundial total de etanol. Os EUA e o Brasil foram os maiores consumidores, respon- dendo, respectivamente, por $59,83 \%$ e $23,65 \%$, do consumo mundial de etanol e juntos representaram uma participação total no consumo de $83,5 \%$. As participações estadunidense e brasileira de etanol no consumo total de biocombustíveis foram $46,22 \%$ e $18,27 \%$, respectivamente. As Tabelas 11,12 e 13 são apresentadas e analisadas em conjunto, dado que elas relacionam a produção e o consumo mundial de combustíveis líquidos, biocombustíveis e etanol, respectivamente.

Os biocombustíveis representam uma pequena parte do total de combustíveis líquidos produzidos e consumidos mundialmente. A oferta e demanda para combustíveis ainda é bastante direcionada para os derivados de petróleo. Em 2011, os biocombustíveis representaram $2,40 \%$ da produção e $2,07 \%$ do consumo mundial total de combustíveis líquidos. A participação do etanol foi menor ainda, $1,71 \%$ da produção mundial e 1,60\% do consumo. Contudo, a produção e o consumo de etanol relacionado com o total de biocombustíveis são praticamente opostos, pois, no mesmo ano, o etanol representou $71,12 \%$ da produção mundial de biocombustíveis e $77,24 \%$ do consumo. A Figura 8 traz o consumo final energético de etanol para 
Tabela 10 - Dados dos dez maiores consumidores mundiais de etanol e a participação no consumo total de etanol e de biocombustíveis em 2011

\begin{tabular}{ccccc}
\hline Região & $\begin{array}{c}\text { Etanol } \\
\left(\mathrm{m}^{3}\right)\end{array}$ & $\begin{array}{c}\text { Participação etanol/total mundial de } \\
\text { etanol (\%) }\end{array}$ & $\begin{array}{c}\text { Participação etanol/total mundial dos } \\
\text { biocombustíveis (\%) }\end{array}$ \\
\hline 1 & EUA & 48.141 .819 & 59,83 & 46,22 \\
2 & Brasil & 19.027 .667 & 23,65 & 18,27 \\
3 & Canadá & 2.404 .080 & 2,99 & 2,31 \\
4 & China & 2.175 .120 & 2,70 & 2,09 \\
5 & Alemanha & 1.516 .860 & 1,89 & 1,46 \\
6 & França & 915.840 & 1,14 & 0,88 \\
7 & Reino Unido & 641.088 & 0,80 & 0,62 \\
8 & Espanha & 457.920 & 0,57 & 0,44 \\
9 & Austrália & 429.300 & 0,53 & 0,41 \\
10 & Suécia & 400.680 & 0,50 & 0,38 \\
\hline
\end{tabular}

Fonte: Elaboração própria a partir de EIA (2012b).

Tabela 11 - Produção e consumo mundial de combustíveis líquidos para o período de 2005 a 2011 (milhões m³)

\begin{tabular}{cccccccc}
\hline Identificação & 2005 & 2006 & 2007 & 2008 & 2009 & 2010 & 2011 \\
\hline Produção & $4.842,50$ & $4.853,95$ & $4.859,68$ & $4.905,47$ & $4.802,44$ & $4.922,64$ & $5.008,50$ \\
Consumo & $4.808,16$ & $4.865,40$ & $4.922,64$ & $4.922,64$ & $4.808,16$ & $4.922,64$ & $5.037,12$ \\
\hline
\end{tabular}

Fonte: Elaboração própria a partir de EIA (2012b).

Tabela 12 - Produção e consumo mundial de biocombustíveis para o período de 2005 a 2011 (milhões m³)

\begin{tabular}{ccccccccc}
\hline Identificação & 2005 & 2006 & 2007 & 2008 & 2009 & 2010 & 2011 \\
\hline Produção & 33,49 & 40,98 & 52,92 & 69,56 & 75,92 & 87,44 & 85,49 \\
Consumo & 28,65 & 36,03 & 46,72 & 63,39 & 73,30 & 81,28 & 80,46 \\
\hline
\end{tabular}

Fonte: Elaboração própria a partir de EIA (2012b).

Tabela 13 - Produção e consumo mundial de etanol para o período de 2005 a 2011 (milhões m³)

\begin{tabular}{ccccccccc}
\hline Identificação & 2005 & 2006 & 2007 & 2008 & 2009 & 2010 & 2011 \\
\hline Produção & 33,49 & 40,98 & 52,92 & 69,56 & 75,92 & 87,44 & 85,49 \\
Consumo & 28,65 & 36,03 & 46,72 & 63,39 & 73,30 & 81,28 & 80,46 \\
\hline
\end{tabular}

Fonte: Elaboração própria a partir de EIA (2012b).

o período de 2000 a 2011 no Brasil.

Entre os anos 2000 e 2006, a produção ficou na faixa 5,3-6,3 mil $10^{3}$ tep, apresentando um salto a partir de 2008 e chegando a 12 mil $10^{3}$ tep. O etanol hidratado representou, em 2011, $60,51 \%$ da produção total de etanol, enquanto que o anidro foi de $39,49 \%$. Em 2001, esta proporção era inversa, onde o anidro era responsável pela maior parte da produção, com $56,52 \%$, contra 43,48\% de etanol hidratado. De 1990 até 2004, o Brasil importou por ano, em média, $6 \%$ do etanol consumido internamente. Neste mesmo período, foi exportado por ano, em média, 3,81\%.
Assim, as possibilidades para o etanol são muitas. No que se refere à sua fabricação, além da produção primária, a partir de biomassas agrícolas, o mesmo pode ser obtido de materiais celulósicos, como resíduos agrícolas e resíduos do primeiro ciclo de obtenção de etanol (bagaço da cana-de-açúcar, por exemplo). O etanol oriundo de material celulósico é chamado de "etanol de segunda geração", o qual pode ser produzido por um processo de hidróliseácida ou enzimática, semelhante ao utilizado com matérias amiláceas. Contudo, as enzimas necessárias para obter o etanol de segunda geração são diferentes das utilizadas, 


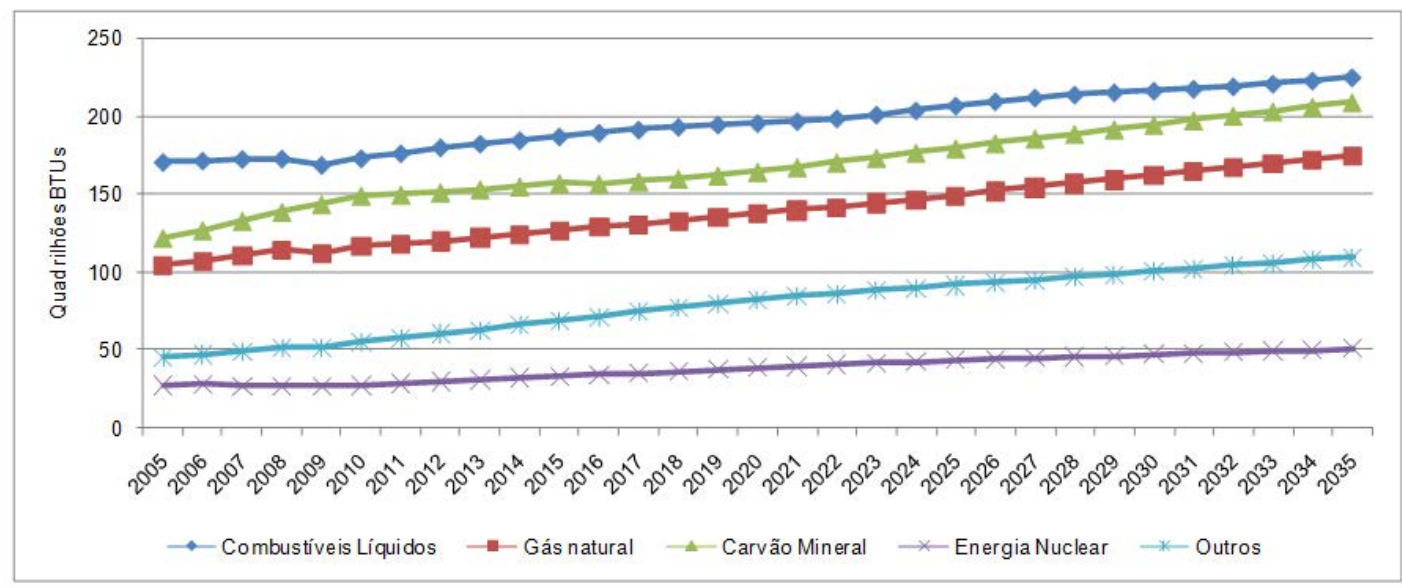

Figura 8 - Consumo final energético de etanol (álcool etílico) em $10^{3}$ tep, no Brasil, no período 2000 a 2011

Fonte: Elaboração própria, a partir de Brasil (2013).

por exemplo, no milho. Estudos técnicos e econômicos estão sendo realizados com a finalidade de diminuir o atual custo das enzimas, a fim de tornar o etanol celulósico economicamente viável e com seu advento a produtividade de etanol por hectare pode dobrar (BENSUSSAN, 2008).

Somam-se a isso as possibilidades do etanol servir com o insumo para a indústriapetroquímica na produção de uma série de polímeros-polietileno (PE); polipropileno (PP); e policloreto de vinila (PVC). E a sua utilização como insumo para extração de hidrogênio, o qual, por sua vez, gera eletricidade, alimentando automóveis leves movidos porcélulas a combustível. Neste sentido, destaca-se a produção de plásticos já iniciada pela Braskem, que conta com 18 produtos de polietileno produzidos a partir de matérias primas renováveis (BNDES; CGEE, 2008; BENSUSSAN, 2008; BRASKEM, 2013).

Em termos setoriais, no setor de transportes, o etanol e a gasolina produzidos são consumidos totalmente pelo setor de transportes brasileiro. Na Tabela 14, observa-se a evolução da produção, consumo e exportação de etanol para os anos selecionados.

Para todos os períodos, a produção de etanol aumenta. Destaca-se o aumento das exportações de etanol, contudo, a partir de 2025, as mesmas podem diminuir, pois o crescimento do consumo ocorre a taxas maiores do que o da produção. No longo prazo, espera-se que o Brasil possa produzir etanol celulósico. Esta possibilidade é bastante apontada, contudo a produção majoritária de etanol se dá a partir da cana-de-açúcar.

As projeções mundiais apontam para uma expansão do consumo de energia primária, bem como para o crescimento econômico das economias. Destaca-se que os países não membros da OCDE devem crescer a patamares maiores que os países membros. O Brasil também acompanha esta expansão do consumo de energia. Os combustíveis líquidos, bem como o etanol, também seguem este aumento. Na Tabela 15, observa-se a produção e o consumo total de combustíveis líquidos para o mundo. Em todos os períodos, tanto a produção quanto o consumo de combustíveis líquidos

Tabela 14 - Produção, consumo e exportação de etanol, projetados para os anos 2015, 2020, 2025 e 2030 (mil m³)

\begin{tabular}{ccccc}
\hline Identificação & 2015 & 2020 & 2025 & 2030 \\
\hline Produção & 38.594 & 51.547 & 57.198 & 61.875 \\
Importação & 0 & 0 & 0 & 0 \\
Exportação & 13.360 & 17.080 & 16.684 & 9.518 \\
Perdas/ ajustes & 332 & -2.025 & 224 & 142 \\
Consumo total & 25.566 & 32.442 & 40.740 & 52.498 \\
Consumo final & 25.566 & 32.442 & 40.740 & 52.498 \\
Consumo final não energético & 333 & 230 & 160 & 110 \\
Consumo final energético & 25.233 & 32.212 & 40.580 & 52.388 \\
Transportes & 25.233 & 32.212 & 40.580 & 52.388 \\
Rodoviário & 25.233 & 32.212 & 40.580 & 52.388 \\
\hline
\end{tabular}

Fonte: Brasil (2007, p.83). 
Tabela 15 - Produção e consumo mundial de combustíveis líquidos (milhões de barris por dia) para os anos 2015. 2020. 2025. 2030 e 2035

\begin{tabular}{lrrrrr}
\hline Identificação & 2015 & 2020 & 2025 & 2030 & 2035 \\
\hline Produção (convencionais + não convencionais) & 93,3 & 97,6 & 103,3 & 108,0 & 112,2 \\
Produção de convencionais & 87,2 & 89,8 & 93,6 & 96,5 & 99,1 \\
Produção de não convencionais & 6,1 & 7,8 & 9,7 & 11,5 & 13,1 \\
Produção de biocombustíveis & 2,4 & 3 & 3,8 & 4,4 & 4,7 \\
Consumo & 93 & 98 & 103 & 108 & 112 \\
\hline
\end{tabular}

Fonte: Elaboração própria a partir de EIA (2012b).

Tabela 16 - Produção e consumo brasileiro de combustíveis líquidos (milhões de barris por dia) para os anos $2015,2020,2025,2030$ e 2035

\begin{tabular}{lrrrrr}
\hline Identificação & 2015 & 2020 & 2025 & 2030 & 2035 \\
\hline Produção (convencionais + não convencionais) & 3,8 & 4,7 & 5,5 & 6,0 & 6,5 \\
Produção de convencionais & 2,9 & 3,5 & 4,1 & 4,5 & 4,8 \\
Produção de não convencionais & 0,9 & 1,1 & 1,4 & 1,5 & 1,7 \\
Consumo & 3 & 3 & 3 & 4 & 4 \\
\hline
\end{tabular}

Fonte: Elaboração própria a partir de EIA (2012b).

Tabela 17 - Produção e consumo nacional de etanol (milhões de barris por dia) para os anos 2015, 2020, 2025 e 2030

\begin{tabular}{lcccc}
\hline Etanol & 2015 & 2020 & 2025 & 2030 \\
\hline Demanda & 0,44 & 0,56 & 0,70 & 0,90 \\
Produção & 0,66 & 0,89 & 0,99 & 1,07 \\
\hline
\end{tabular}

Fonte: Elaboração própria a partir de Brasil (2007).

aumentam.

Os dados demonstram um equilíbrio entre a oferta e o consumo de combustíveis líquidos. Tanto a produção quanto o consumo total de combustíveis líquidos aumentam em 20\% de 2015 para 2035. A produção passa de 93,3 milhões de barris por dia e a demanda para 93 milhões de barris por dia. Com o crescimento projetado, os biocombustíveis representam, em média, 3,5\% da produção total de combustíveis líquidos. Esta participação é crescente, passando de 2,57\%, em 2015 , para $4,19 \%$, em 2030 . No que confere aos dados nacionais, com base no estudo do EIA (2011), estes são apresentados na Tabela 16.

Os dados demonstram um distanciamento entre produção e consumo de combustíveis líquidos. O consumo total de combustíveis líquidos aumenta em 33\% de 2015 para 2035, enquanto que a produção eleva-se em $71 \%$. Essa diferença pode ser explicada com a projeção do aumento das exportações de etanol, sinalizadas pelo Brasil (2007). A produção passa de 3,8 milhões de barris por dia e a demanda para 6,5 milhões de barris por dia. A participação de combustíveis líquidos não convencionais, no total da produção de líquidos, é em média de $24,4 \%$ a cada 5 anos. A participação de combustíveis líquidos convencionais diminui em dois períodos: $2015 / 2020,-1,85$ pontos percentuais; e 2030 para $2035,1,15$ pontos percentuais. Em relação à produção de etanol, os dados projetados de consumo e produção são expostos na Tabela 17.

Os dados de consumo e produção de etanol estão projetados para até o ano de 2030 . A produção de etanol aumenta em mais de $100 \%$, de 2015 para 2030, enquanto que o consumo eleva-se $60 \%$. Como já mencionado, a produção de etanol brasileira supera seu consumo interno, dado que parte desta produção é destinada ao consumo externo. Contudo, a quota do consumo interno cresce nos períodos selecionados. Cabe destacar 
que a participação do etanol na demanda nacional apresenta um crescimento, passando de 17,33\%, em 2015, para 22,20\%, em 2030.

\section{CONSIDERAÇÕES FINAIS}

Inicialmente, buscou-se apresentar uma breve definição e classificação de energia, a qual é a fonte para produção de bens e serviços que atendam as necessidades humanas, quando relacionada ao mundo econômico. Ela não pode ser criada e, sim, transformada e redistribuída a partir de fontes energéticas já existentes em outras fontes de consumo final. No caso do etanol, ele tem sua origem primária na energia solar, a qual é captada pela biomassa e é, então, transformada em combustíveis líquidos, por exemplo.

Ao buscar apresentar os cenários futuros para a produção de energia, mais especificamente as possibilidades e perspectivas para a demanda e a oferta de etanol, verificou-se que as projeções não apresentam perspectivas de mudanças na matriz energética mundial, bem como na brasileira. $\mathrm{Ou}$ seja, ao menos até 2030, o petróleo e seus derivados permanecem como os principais responsáveis em atender a demanda de energia necessária à produção de bens e serviços para a sociedade. O setor de transportes rodoviário, que consome basicamente a gasolina e o etanol produzidos, não apresenta um avanço em relação aos combustíveis líquidos convencionais, representando em média 3,5\% do total de combustíveis líquidos produzidos e consumidos anualmente. Em relação ao Brasil, as projeções para a produção e o consumo de etanol apresentam-se otimistas, com possibilidades do aumento dos níveis de exportação.

As transformações e mudanças na matriz energética estão ligadas a processos de desenvolvimento tecnológico, bem como ao crescimento econômico e populacional, refletindo no aumento da produção e do consumo mundial de energia, os quais cresceram ao longo do tempo. Desta forma, são apontadas projeções futuras de crescimento do consumo e da produção energética para os países não membros da OCDE, em patamares superiores aos projetados para países membros. As projeções brasileiras também refletem este crescimento.

Em relação ao etanol, a matéria prima que predomina no Brasil para sua obtenção é a cana de açúcar. Contudo, esta não é a única fonte deste biocombustível, o qual pode ser obtido de diferentes culturas como a beterraba, a batata doce, o trigo, o milho, o sorgo sacarino e granífero. Neste sentido, as oportunidades de obtenção de etanol podem estar voltadas ao desenvolvimento regional, considerando matérias primas disponíveis nos locais de instalações futuras de unidades produtoras de etanol.

Por fim, nota-se que as perspectivas para o consumo, tanto de combustíveis líquidos quanto de etanol, são otimistas, demonstrando, assim, possibilidades para a expansão da produção. Destaca-se também que para o período analisado não está prevista uma ruptura ou quebra estrutural da atual matriz energética, mesmo com um pequeno aumento da participação das fontes renováveis no total de energia demandada.

\section{REFERÊNCIAS BIBLIOGRÁFICAS}

ACIOLI, José de Lima. Fontes de energia. Brasília: Editora UnB, 1994.

BANCO NACIONAL DO DESENVOLVIMENTO ECONÔMICO E SOCIAL. BNDES; CENTRO DE GESTÃO E ESTUDOS ESTRATÉGICOS. CGEE (Org.). Bioetanol de cana-de-açúcar: energia para o desenvolvimento. Rio de Janeiro: BNDES, 2008. Disponível em: <http://www.bioetanoldecana.org/pt/ download/bioetanol.pdf>. Acesso em: 23 mar. 2012.

BENSUSSAN, Jaques Alberto. Etanol, um presente com passado e futuro. Textos para Discussão FEE $n^{\circ}$ 50 FEE, Porto Alegre, 2008. Disponível em: <http:// www.fee.tche.br/sitefee/download/tds/050.pdf $>$. Acesso em: 09 jan. 2013.

BP. BP statistical review of world energy. Frederick: BP, 2012. Disponível em: <http://www.bp.com/statisticalreview>. Acesso em: 16 maio 2012.

BRASIL. Ministério de Minas e Energia. Plano Nacional de Energia 2030. Colaboração Empresa de Pesquisa Energética. Brasília: MME: EPE, 2007. Disponível em: <http://www.mme.gov.br/mme/galerias/arquivos/ publicacoes/pne_2030/PlanoNacionalDeEnergia2030. pdf>. Acesso em: 07 jan. 2013.

BRASIL. Ministério de Minas e Energia. Publicações e indicadores: balanço energético nacional. Disponível em < http://www.mme.gov.br/spe/menu/publicacoes. html>. Acesso em: 18 fev. 2013.

BRASKEM. Braskem. Consulta de produtos. Disponível em: <http://www.braskem.com.br/site.aspx/ Consultar 
-Produtos? $\operatorname{codProduto}=629 \& \mathrm{grd}=$ true $\&$ Familia $=6$ $\& n m F a m=$ Polietileno $\% 20$ Verde $\&$ CtgFam $=\&$ Aplica $\mathrm{cao}=\&$ Processo $=\&$ CurrentPage $=0>$. Acesso em: 31 jan. 2013.

\section{CENTRO NACIONAL DE REFERÊNCIA EM} BIOMASSA. CENBIO. Conceituando biomassa. São Paulo, 2012. Disponível em <http://cenbio.iee. usp.br/saibamais/conceituando.htm>. Acesso em: 26 nov. 2012.

CORTEZ, Luís Augusto Barbosa et al. Biomassa no Brasil e no mundo. IN: CORTEZ, Luís Augusto Barbosa et al. (Orgs.). Biomassa para energia. Campinas, SP: Editora da Unicamp, 2008. cap. 1, p. 15-30.

EMPRESA DE PESQUISA ENERGÉTICA. EPE. Balanço energético nacional 2011: ano base 2010. Rio de Janeiro: EPE, 2011. Disponível em: <https:// ben.epe.gov.br/downloads/Relatorio_Final_ BEN_2011.pdf>. Acesso em: 9 jan. 2013.

GOLDEMBRG, José; LUCON, Oswaldo. Energia, meio ambiente \& desenvolvimento. São Paulo: Editora da USP, 2008

HINRICHS, Roger A.; KLEINBACH, Merlin. Energia e meio ambiente. Tradução técnica de Flávio Maron Vichi, Leonardo Freire de Mello. São Paulo: Pioneira Thomson Learning, 2003.

REIS, Lineu Belicodos et al. Energia, recursos naturais e a prática do desenvolvimento sustentável. 2 ed. rev. e atual. Barueri: Manole, 2012.

\section{U.S. ENERGY INFORMATION ADMINIS-}

TRATION. EIA. International energy outlook 2011. Washington: EIA, 2012b. Disponível em: $<$ http://www.eia.gov/oiaf/aeo/tablebrowser/\#r elease $=$ IEO2011\&subject $=0$-IEO2011\&table $=1$ -IEO2011\&region $=0-0 \&$ cases $=$ Reference-0504a_1630>. Acesso em: 14 dez. 2012.

\section{U.S. ENERGY INFORMATION ADMINISTRA-} TION. EIA. What is energy? explained: forms of energy. 2012a. Disponível em: <http://www.eia.gov/ energyexplained/index.cfm?page=about_forms_of_ energy >. Acesso em: 10 out. 2012.

\section{U.S. ENERGY INFORMATION ADMIN-} ISTRATION. EIA. International energy outlook 2011. Washington: EIA, 2011. Disponível em: <http://205.254.135.7/forecasts/ieo/ pdf/0484(2011).pdf>. Acesso em: 4 abr. 2013.
WORLD BANK. Data. Disponível em: <http:// data.worldbank.org/>. Acesso em: 10 abr. 2013. 